\title{
ANALISIS DINAMIKA TINGKAT KEKERUHAN DAN KEDALAMAN RELATIF PERAIRAN DI WADUK SUTAMI KABUPATEN MALANG
}

\author{
Alfi Nur Rusydi ${ }^{\mathrm{a}, *}$, Ferryati Masitoh ${ }^{\mathrm{b}}$ \\ aProgram Studi Manajemen Sumber Daya Perairan, Fakultas Perikanan dan Ilmu Kelautan, Universitas \\ Brawijaya, Malang, Indonesia \\ brogram Studi Ilmu Geografi, Fakultas Ilmu Sosial, Universitas Negeri Malang, Malang, Indonesia \\ *Koresponden penulis: alfi.nurrusydi@ub.ac.id
}

\begin{abstract}
Abstrak
Penurunan fungsi waduk Sutami yang berupa sedimentasi intensif dalam kurun waktu 2013-2019 perlu dilakukan upaya identifikasi dan monitoring. Upaya ini dilakukan dengan memanfaatkan teknologi penginderaan jauh yang bertujuan untuk menganalisis dinamika sedimentasi perairan berdasarkan kedalaman relatif air dan tingkat kekeruhan air di waduk Sutami pada musim kemarau tahun 2013-2019. Citra satelit Landsat 8 OLI diolah untuk mendapat nilai Relative Water Depth (RWD) dan Normalized Difference Turbidity Index (NDTI). Hasil penelitian menunjukkan bahwa pada tahun 2013 hingga tahun 2019, kenampakan air keruh cenderung teridentifikasi di bagian timur waduk yang juga merupakan inlet waduk Sutami. Analisis kedalaman relatif air dilakukan untuk mengetahui dampak sedimentasi terhadap perubahan kedalaman perairan. Tingkat kekeruhan dan kedalaman relatif perairan tidak berhubungan langsung yang kuat secara statistik. Semakin keruh suatu perairan, maka belum tentu kedalaman relatif pada perairan tersebut menjadi semakin dangkal. Proses sedimentasi perairan di waduk Sutami yang terjadi pada tahun 2013-2019 menunjukkan bahwa proses tersebut dipengaruhi oleh tingkat kekeruhan.
\end{abstract}

Kata kunci: kekeruhan, kedalaman perairan, kemarau, NDTI, waduk

\begin{abstract}
Decrease of Sutami DAM's function which is intensive sedimentation within time of 2013-2019 requires to be identified and monitored. It used remote sensing technology to analyze water sedimentation dynamics based on relative water depth and turbidity level in Sutami DAM on dry season of 2013-2019. Satellite imagery of Landsat 8 OLI was processed to obtain both Relative Water Depth and Normalized Difference Turbidity Index (NDTI) values. The results show that turbid water appearance prone to be identified throughout the year of 2013-2019 in east of the DAM which is Sutami DAM's inlet. Relative water depth analysis was done to identify sedimentation impacts to water depth changes. Turbidity level and relative water depth did not directly strong correlate to each other statistically. The more turbid water, not necessary the shallower water. Sedimentation process occurred in Sutami DAM within time of 2013-2019 shows that it had been influenced by turbidity level.
\end{abstract}

Keywords: turbidity, water depth, dry season, NDTI, DAM

\section{PENDAHULUAN}

Waduk Sutami yang dikenal dengan bendungan Sutami atau bendungan Karangkates terletak di Kecamatan Sumberpucung, Kabupaten Malang, Provinsi Jawa Timur. Waduk ini menahan sungai Brantas dan memiliki sumber air yang berasal dari mata air Gunung Arjuno dan air hujan. Saat ini, waduk Sutami dikelola oleh Perusahaan Umum Jasa Tirta 1. Waduk mempunyai fungsi utama sebagai pengendali aliran debris [1], pencegah penumpukan sedimen atau pengendapan [2], pembangkit listrik [1], penyediaan air irigasi [3], dan pariwisata [4] serta perikanan darat [5]. Waduk ini difungsikan sebagai pengendali banjir dengan periode ulang 50 tahun. Periode tersebut jika dikonversikan ke dalam debit adalah setara dengan $1.560 \mathrm{~m}^{3} / \mathrm{detik}$. Tenaga air di waduk ini juga mampu membangkitkan listrik dengan daya $3 \times 35.000 \mathrm{kWh}$ (488 juta $\mathrm{kWh} /$ tahun). Waduk Sutami juga mampu 
menyediakan air irigasi $24 \mathrm{~m}^{3} /$ detik pada musim kemarau yang dapat mengairi lahan seluas 34.000 ha melalui pengairan ke hilir [6]. Perikanan darat di waduk Sutami dilakukan dengan metode jaring terapung atau keramba. Sekitar $90 \%$ air di waduk Sutami dimanfaatkan untuk irigasi pertanian. Fungsi waduk Sutami tersebut ternyata cukup penting untuk menjaga ketahanan pangan, energi, dan pengendalian banjir di wilayah Provinsi Jawa Timur [6].

Kondisi waduk Sutami ternyata mengalami penurunan fungsi waduk berupa penurunan kapasitas pada tahun 2018 [7]. Penurunan kapasitas ini terjadi karena kerusakan daerah tangkapan waduk yang menyebabkan sedimentasi yang sangat intensif. Erosi yang terjadi di daerah tangkapan air yang berada di hulu merupakan faktor dominan yang memengaruhi penambahan material sedimen pada daerah yang lebih rendah [8]. Waduk Sengguruh sebagai waduk kontrol sedimentasi di waduk Sutami pada tahun 2018 mempunyai kapasitas tampungan $0,98 \mathrm{~m}^{3}$ atau sekitar 5,2\% dari kondisi tampungan awal. Volume sedimentasi di Waduk Sutami terukur sebesar $\pm 23,881 \mathrm{~m}^{3}$. Perusahaan Jasa Tirta 1 sebagai pengelola waduk Sutami melaporkan bahwa pada tahun 2018 telah terjadi percepatan proses sedimentasi. Tindakan pengerukan telah dilakukan di waduk Sengguruh dan waduk Sutami, serta waduk Wlingi, waduk Selorejo dan waduk Siruar dengan total pengerukan sebesar 1.315.953 $\mathrm{m}^{3}$ [7].

Permasalahan sedimentasi merupakan masalah yang sangat penting untuk segera ditangani di suatu waduk [9]. Sedimentasi dapat mengurangi kapasitas tampungan suatu waduk [10], [11] dan memengaruhi kondisi kualitas air [12], [13]. Sedimentasi mempunyai hubungan dengan tingkat kekeruhan dan kedalaman perairan [14], [15]. Air yang keruh dapat diidentifikasi sebagai air yang mengandung material sedimen atau bahan pencemar, sehingga jika semakin keruh air, maka air tersebut akan memberikan kontribusi lebih besar terhadap proses sedimentasi [14]. Proses sedimentasi dapat terjadi jika arus yang membawa material tersebut mengalami penurunan kecepatan aliran secara signifikan [16]. Penurunan kecepatan ini dapat dipengaruhi oleh perubahan topografi dari gradien topografi miring ke topografi yang lebih datar. Semakin kuat arus air yang mengangkut material sedimen dan semakin miring gradien topografi suatu penampang saluran aliran airnya, maka kemungkinan proses sedimentasi untuk terjadi cenderung semakin kecil [17].

Identifikasi proses sedimentasi pada suatu perairan dapat dikontrol dengan faktor kedalaman perairan. Perairan akan teridentifikasi sebagai perairan yang mengalami sedimentasi jika kondisi perairan dangkal tetapi keruh [18], [19]. Perairan yang dalam tetapi keruh juga dapat menjadi indikator bahwa perairan tersebut membawa material sedimen terlarut dalam jumlah yang cukup banyak, tetapi arus air cenderung kuat, sehingga proses yang telah terjadi bukan pengendapan, melainkan penggerusan dasar perairan [19], [20].

Penanganan masalah sedimentasi merupakan usaha yang sangat penting untuk dilakukan akan dapat berjalan dengan efektif dan efisien jika didukung oleh teknologi, terutama dalam proses identifikasi dan monitoring [21]. Teknologi ini harus dapat diandalkan untuk identifikasi dan monitoring pada area perairan yang luas seperti waduk Sutami. Penginderaan Jauh merupakan salah satu teknologi yang dapat dimanfaatkan untuk kegiatan pengukuran dan monitoring proses sedimentasi pada daerah yang memiliki cakupan luas [13], [22], [23]. Penginderaan jauh memiliki keunggulan yaitu proses perolehan data spasial yang cukup luas dalam waktu yang relatif singkat [24], [25]. Hal ini tidak dapat dilakukan dengan survei konvensional terestrial yang umumnya berlangsung lebih lama [21], [24]. Identifikasi hasil proses sedimentasi pada suatu obyek perairan dapat dilakukan dengan memanfaatkan respons spektral obyek perairan tersebut terhadap panjang gelombang tertentu [26]. 
Tingkat kekeruhan air merupakan faktor penting dan dominan yang dipertimbangkan dalam identifikasi kondisi perairan menggunakan penginderaan jauh [27], [28]. Kekeruhan merupakan ukuran hamburan cahaya yang masuk ke dalam suatu obyek perairan yang dipengaruhi oleh kandungan material terlarut dalam air [28]. Identifikasi hasil sedimentasi pada suatu perairan dapat dilakukan dengan menggunakan Normalized Difference Turbidity Index (NDTI) yang merupakan rasio antara pantulan band merah dan spektrum hijau untuk analisis tingkat kekeruhan perairan di suatu waduk [9], [27]. Pantulan spektral yang berasal dari obyek air keruh akan menyerupai kenampakan obyek lahan terbuka [29], [30]. Data satelit Landsat dapat digunakan secara efektif untuk identifikasi dan analisis tingkat kekeruhan di perairan [9], [28], [31].

Kekeruhan pada perairan pada dasarnya merupakan suatu faktor yang dapat menentukan dinamika topografi dasar perairan dengan berbagai variasi kedalaman, seperti alur kelokan sungai (meandering), parit (gully), tanggul, dan dapat memengaruhi struktur perlapisan sedimen [32]-[34]. Hal ini mengindikasikan bahwa terdapat hubungan antara tingkat kekeruhan dan kedalaman perairan pada proses sedimentasi di suatu perairan. Penginderaan jauh memberikan berbagai macam keuntungan dalam pengukuran kedalaman perairan yang meliputi durasi pengukuran lebih singkat, biaya dan tenaga lebih efisien [35], [36]. Citra satelit optis dalam teknologi penginderaan jauh telah terbukti dapat dimanfaatkan secara luas untuk mengukur kedalaman perairan [36], [37]. Pengukuran kedalaman perairan dapat dilakukan dengan memanfaatkan pantulan optis pada kolom perairan tersebut [38], [39]. Kriteria citra optis yang banyak dimanfaatkan untuk analisis ke dalam perairan adalah citra multispektral [40].

Penelitian sebelumnya berusaha mengindentifikasi variasi kedalaman suatu perairan secara relatif dengan memanfaatkan citra multispektral seperti Landsat (Land
Satellite) Enhanced Thematic Mapper+ (ETM+) [37], [41] dan Landsat 8 [35]. Pengukuran kedalaman perairan menggunakan formula Relative Water Depth yang merupakan parameter independen albedo bawah yang mengindikasikan tutupan dasar perairan oleh lamun atau material pasir pada bagian perairan dengan kedalaman yang sama [42]. Kedangkalan suatu perairan ditentukan dari keberadaan atau tingkat keterlihatan tutupan perairan oleh lamun atau pasir. Semakin dangkal suatu tubuh perairan, maka seharusnya obyek lamun atau material dasar yang menutupi dasar perairan dapat terlihat.

Penelitian ini bertujuan untuk menganalisis dinamika sedimentasi perairan berdasarkan kedalaman relatif air dan tingkat kekeruhan air di waduk Sutami pada musim kemarau tahun 2013-2019. Data citra satelit yang digunakan adalah Landsat 8 Operational Land Imager (OLI). Hasil penelitian ini dapat dimanfaakan sebagai data untuk manajemen sumber daya perairan sekaligus sebagai bahan evaluasi kemampuan teknologi Penginderaan Jauh untuk mengontrol dinamika sedimentasi di waduk Sutami. Penelitian ini juga memberikan kontribusi terhadap peningkatan monitoring secara dini terhadap dampak proses sedimentasi di waduk Sutami.

\section{METODE}

\section{Data}

Data yang digunakan dalam riset ini meliputi data satelit Landsat 8 OLI yang dapat diperoleh dan diunduh pada halaman situs http://earthexplorer.usgs.gov/. Data Landsat 8 yang digunakan adalah data perekaman pada bulan-bulan musim kemarau (Mei-Oktober) tahun 2013 hingga tahun 2019. Data tersebut harus mempunyai keawanan minimal pada daerah sekitar waduk Sutami (Gambar 1). Pemilihan citra dengan tingkat keawanan minimal dilakukan untuk menghindari hamburan dan serapan oleh partikel aerosol yang akan memengaruhi pada kemurnian nilai piksel suatu obyek. Koreksi radiometrik 
dilakukan pada tiap citra satelit yang diamati untuk menghilangkan pengaruh hamburan dan serapan partikel aerosol pada suatu nilai piksel obyek [43].

\section{Pengolahan dan Analisis Data}

Data citra satelit Landsat 8 OLI diolah untuk mendapatkan data kedalaman relatif air dengan menggunakan tool SPEAR Relative Water Depth pada perangkat lunak ENVI. Pada tahap ini, hasil yang diperoleh adalah citra hasil Relative Water Depth pada tiap tahun pengamatan. Relative Water Depth adalah rasio kedalaman perairan bukan nilai absolut kedalaman, sehingga nilai kedalaman yang diperoleh bersifat relatif. Semakin besar nilai rasio Relative Water Depth, maka semakin dangkal suatu obyek perairan, dan begitu pula sebaliknya [42].

Deteksi perubahan (change detection) indeks Relative Water Depth dilakukan antar dua citra dengan tahun pengamatan berurutan. Tahun pengamatan tersebut adalah: tahun 2013-2014, tahun 2014-2015, tahun 20152016, tahun 2016-2017, tahun 2017-2018, dan tahun 2018-2019.

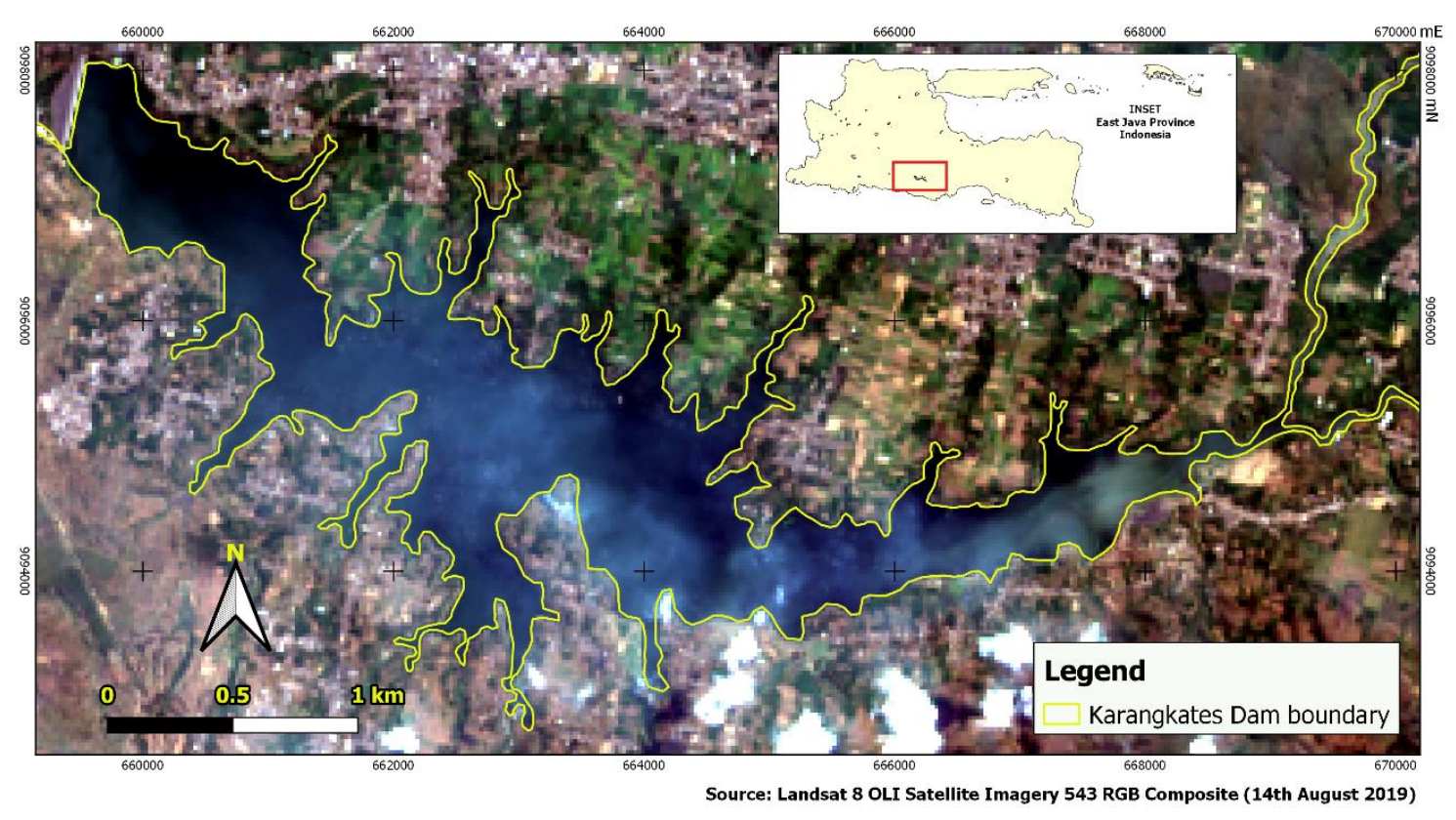

Gambar 1. Peta lokasi penelitian

Analisis tingkat kekeruhan air sebagai salah satu indikator air mengandung material sedimen dilakukan melalui perhitungan Normalized Difference Turbidity Index (NDTI) pada citra satelit Landsat 8 OLI. Normalized Difference Turbidity Index (NDTI) dihitung menggunakan Persamaan 1 sebagai berikut:

$$
\text { NDTI }=\frac{\text { Red }- \text { Green }}{\text { Red }+ \text { Green' }}
$$

dengan keterangan: NDTI adalah indeks kekeruhan; Red adalah band merah pada citra Landsat 8 OLI; Green adalah spektrum hijau pada citra Landat 8 OLI.

Semakin besar indeks NDTI, maka semakin keruh suatu obyek perairan [9]. Deteksi perubahan dilakukan untuk mengetahui dinamika perubahan kondisi kekeruhan di waduk Sutami. Deteksi perubahan nilai NDTI dilakukan antar dua citra dengan tahun pengamatan yang sama dengan RWD. 




Gambar 2. Peta lokasi pengambilan sampel

Analisis statistik dilakukan untuk mengetahui hubungan antara nilai indeks Relative Water Depth dengan nilai NDTI pada 30 titik lokasi sampel di waduk Sutami (Gambar 2). Titik lokasi sampel ditentukan secara merata di bagian tengah waduk. Hal ini dilakukan agar data yang diperoleh tidak terlalu dipengaruhi oleh proses-proses yang ada di tepi waduk, misalnya intensitas sedimentasi dan kedangkalan dasar perairan. Pengaruh yang terlalu dominan, baik sedimentasi maupun kedangkalan dasar perairan akan menyebabkan informasi hubungan kedua variabel tersebut menjadi bias.

\section{HASIL DAN PEMBAHASAN}

Penelitian ini menunjukkan bahwa telah terjadi perubahan tingkat kekeruhan dan kedalaman relatif perairan selama kurun waktu 2013-2019 di waduk Sutami (Gambar 3). Perubahan tersebut menunjukkan pola bahwa semakin banyak material sedimen yang terlarut dalam air, maka air tampak semakin keruh. Material yang terlarut dalam air akan berkontribusi terhadap akumulasi sedimen pada salah satu bagian tubuh perairan akibat perubahan gradien dasar perairan dan penurunan kuat arus air [34]. Jika akumulasi material sedimen tersebut terus terjadi, terutama di bagian dasar perairan dan berlangsung dalam waktu yang lama, maka hal ini akan menyebabkan dasar perairan tersebut berubah menjadi semakin dangkal. Pendangkalan ini ditunjukkan dengan peningkatan nilai Relative Water Depth. 


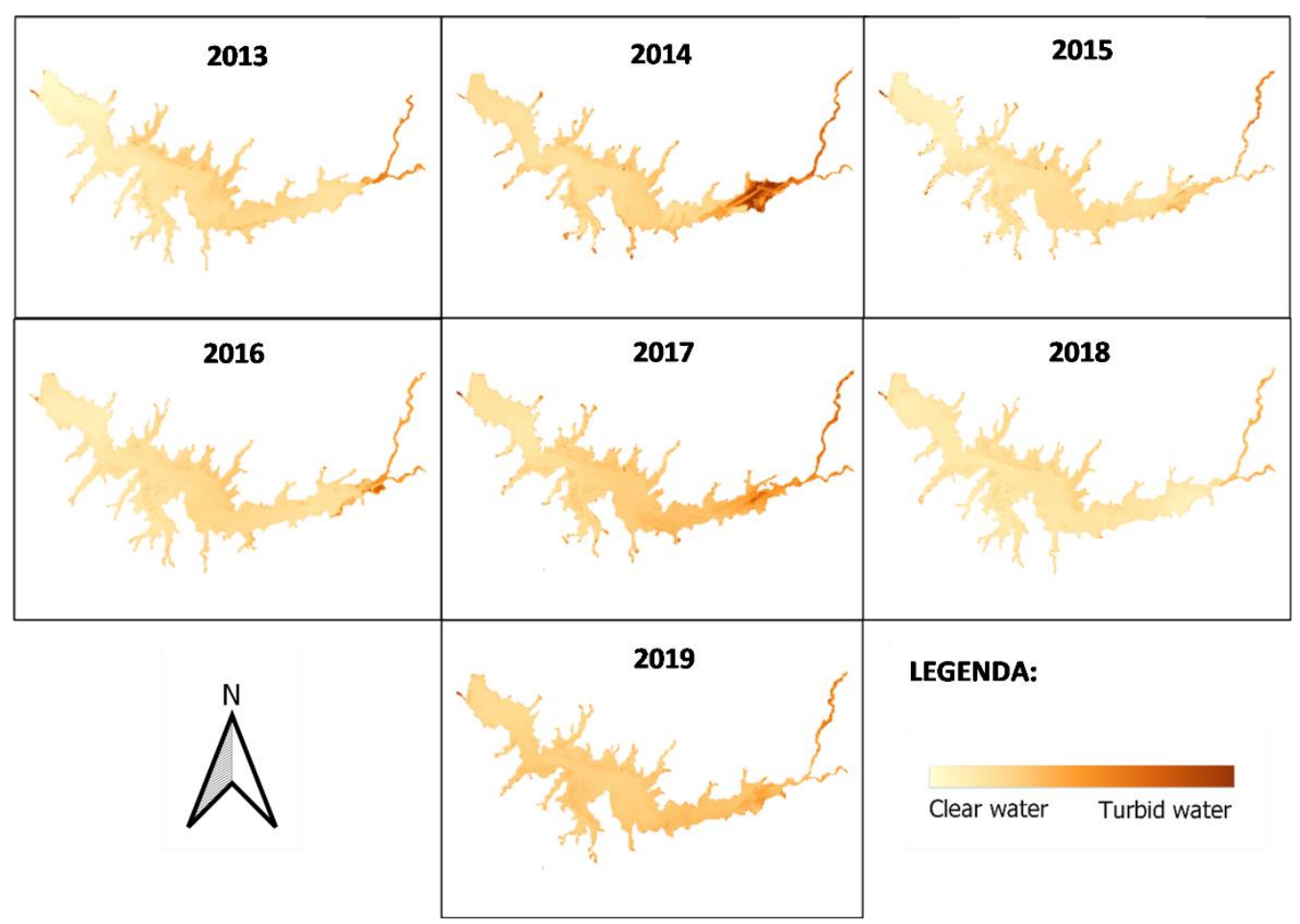

Gambar 3. Peta tingkat kekeruhan perairan Waduk Sutami tahun 2013-2019

Nilai kekeruhan pada peta ditampilkan sebagai warna coklat. Semakin berwarna coklat suatu perairan, maka semakin tinggi tingkat kekeruhan perairan tersebut. Hal ini mengindikasikan kondisi air semakin keruh. Semakin keruh air, maka semakin banyak material sedimen yang terlarut dalam air tersebut [14]. Pada tahun 2013 hingga tahun 2019, kenampakan air keruh cenderung teridentifikasi di bagian timur waduk yang juga merupakan inlet waduk Sutami. Batas daerah pasang surut di Waduk Sutami juga mengalami perubahan karena dinamika sedimentasi dan erosi yang berlangsung di beberapa tempat. Air yang keruh ini diduga berasal dari material sedimen yang terbawa arus sungai Brantas. Tingkat kekeruhan air paling tinggi di bagian inlet waduk terjadi pada pada tahun 2014. Pada tahun 2015, batas daerah pasang surut waduk di bagian sebelah timur mengalami perubahan, berupa penambahan area daratan akibat akumulasi material terlarut yang terendapkan di bagian tersebut.

Perubahan tingkat kekeruhan tahunan juga dianalisis untuk mengetahui dinamika luas area daratan, khususnya di batas daerah pasang surut air waduk Sutami (Gambar 4). Pada tahun 2013-2014, tahun 2016-2017, tahun 20182019 hasil penelitian menunjukkan bahwa telah terjadi penurunan tingkat kekeruhan air. Penurunan tingkat kekeruhan air ini mengakibatkan penurunan tingkat sedimentasi yang terjadi, karena semakin sedikit material terlarut oleh air sungai Brantas yang diendapkan pada bagian tertentu pada waduk Sutami. Hal ini ditandai dengan perluasan batas daerah pasang surut waduk yang diamati berdasarkan perubahan garis perimeter batas daerah pasang surut waduk Sutami. Perluasan batas daerah pasang surut waduk dapat terjadi jika material sedimen yang terlarut sedikit dan kuat arus air cenderung meningkat [19]. Peningkatan kuat arus akan menyebabkan erosi pada beberapa bagian tubuh perairan [20]. Penurunan tingkat sedimentasi dapat terjadi karena beberapa macam faktor. Faktor tersebut meliputi penurunan intensitas erosi pada bagian hulu sungai sebelum inlet sehingga jumlah material terlarut akibat erosi relatif yang masuk ke waduk menjadi relatif lebih 
sedikit. Penurunan intensitas erosi dapat terjadi jika lereng mengalami perubahan kemiringan menjadi lebih landai [44], perubahan intensitas curah hujan [45], dan tindakan konservasi lahan [46]. Penurunan tingkat sedimentasi waduk Sutami juga disebabkan oleh optimalisasi efisiensi tangkapan (trap- efficiency) pada waduk melalui penggalian, pengerukan, dan penggelontoran sedimen. Ketiga kegiatan optimalisasi tersebut merupakan kegiatan yang umum dilakukan untuk mengurangi akumulasi sedimen yang masuk ke dalam waduk [47]-[49]

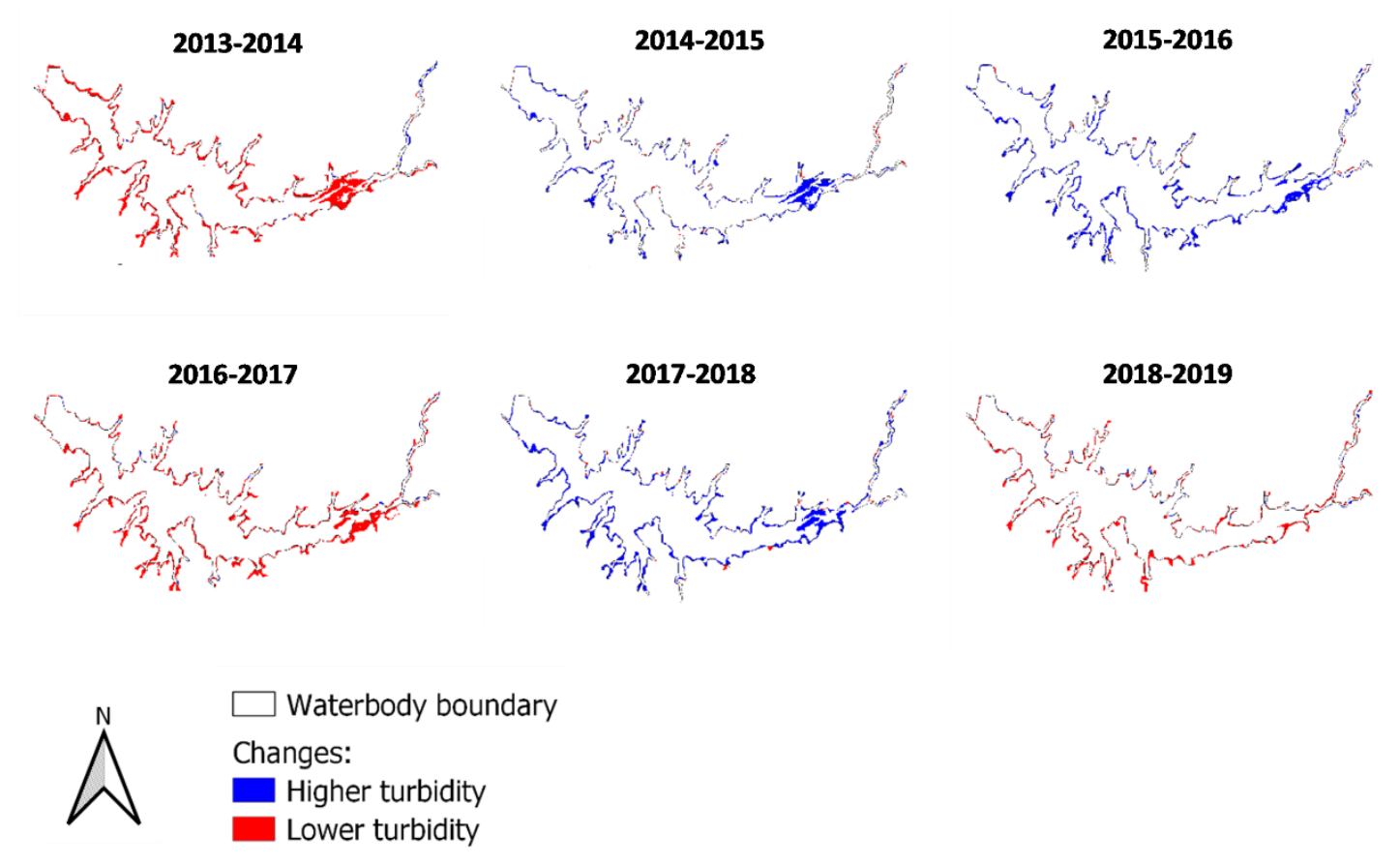

Gambar 4 Peta perubahan tingkat kekeruhan perairan Waduk Sutami tahun 2013-2019

Pada tahun 2014-2015, tahun 2015-2016, dan tahun 2017-2018, terjadi peningkatan tingkat kekeruhan air di Waduk Sutami (Gambar 4). Peningkatan kekeruhan ini berdampak pada penyempitan luas daerah pasang surut air waduk. Beberapa bagian tepi daerah pasang surut waduk mengalami penyempitan area karena semakin banyaknya akumulasi endapan material terlarut di bagian tersebut. Peningkatan tingkat kekeruhan ini dapat disebabkan oleh berbagai macam faktor. Faktor yang memengaruhi hal tersebut antara lain peningkatan intensitas erosi di daerah hulu sebelum inlet waduk. Material hasil erosi tersebut masuk ke dalam sungai dan terbawa oleh arus sungai hingga pada akhirnya masuk ke waduk melalui inlet dan memberikan kontribusi terhadap penambahan jumlah material sedimen [50]. Peningkatan aktivitas pembuangan limbah atau bahan pencemar oleh manusia juga dapat memengaruhi peningkatan tingkat kekeruhan air [14].

Analisis perubahan kedalaman relatif perairan dilakukan untuk mengidentifikasi dinamika proses sedimentasi yang ditandai dengan perubahan tingkat kekeruhan air di waduk Sutami. Analisis kedalaman relatif perairan dilakukan pada rentang tahun yang sama dengan analisis tingkat kekeruhan yakni pada tahun 2013-2019 (Gambar 5). Perbandingan data kedalaman relatif perairan dan kekeruhan menunjukkan bahwa area-area yang mengalami peningkatan tingkat kekeruhan, ternyata diikuti dengan pendangkalan kedalaman relatif perairan, baik pada bagian tepi maupun tengah waduk. Hal ini memberikan pemahaman bahwa pada periode tersebut, semakin air keruh, maka semakin dangkal perairan tersebut secara relatif. Sedimentasi akan berdampak pada pendangkalan dasar perairan, karena 
akumulasi endapan material menutupi dasar perairan tersebut [34].

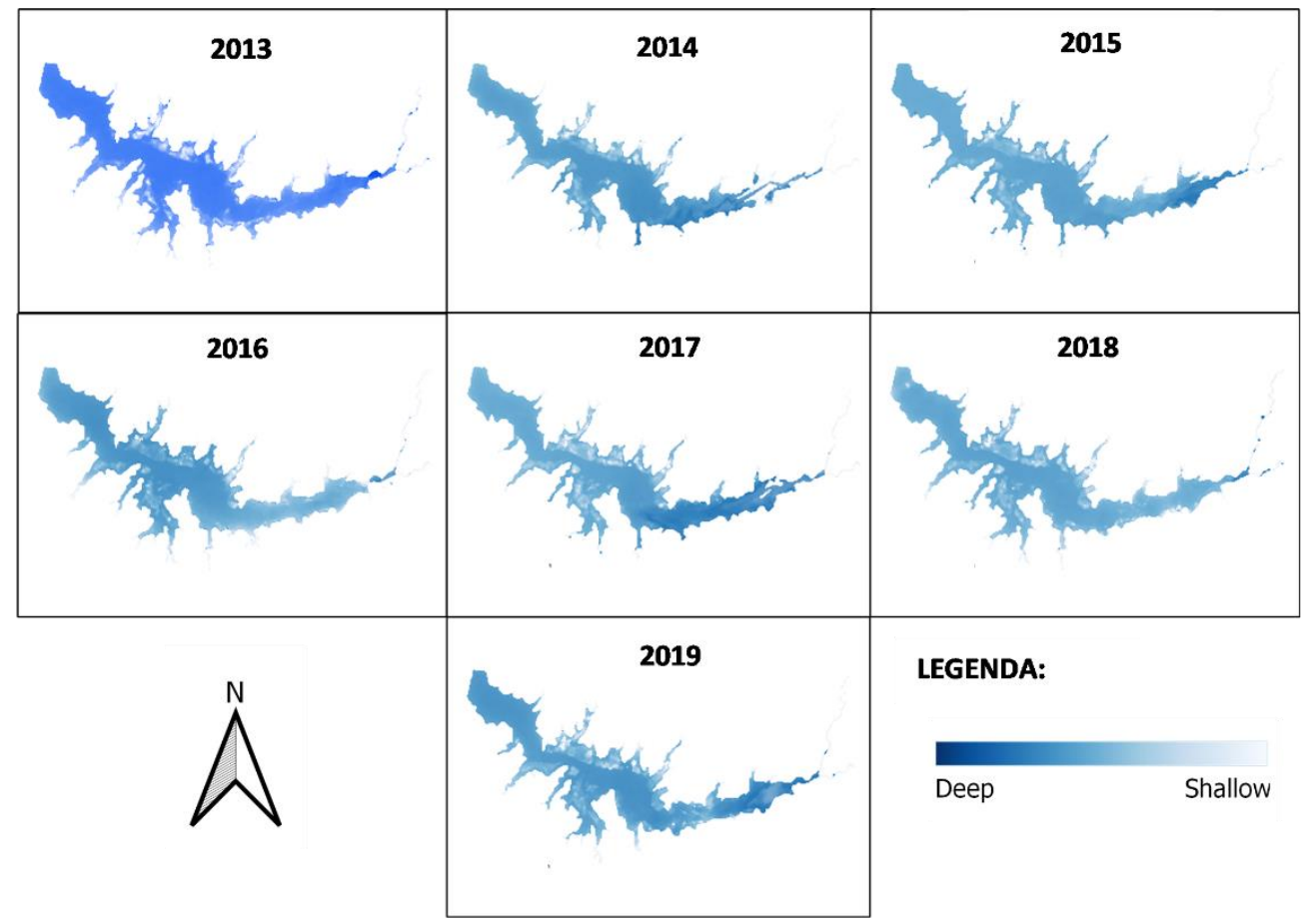

Gambar 5 Peta tingkat kedalaman relatif perairan Waduk Sutami tahun 2013-2019

Hasil penelitian ini menunjukkan bahwa di waduk Sutami, terdapat area-area yang masing-masing berwarna merah pada peta NDTI, tetapi berwarna biru pada peta RWD (Gambar 6). Area tersebut merupakan daerah perairan yang mengalami pendangkalan dan jernih (tidak keruh). Area yang mengalami pendalaman dasar perairan dan tidak keruh ditunjukkan pada area yang berwarna merah pada baik pada peta NDTI maupun peta RWD. Area sedimentasi akibat akumulasi material sedimen dapat diidentifikasi pada area yang berwarna biru baik pada peta NDTI maupun peta RWD. Beberapa area juga tampak berwarna biru pada peta NDTI yang berarti air di area itu mengalami kekeruhan, tetapi area tersebut berwarna merah pada peta RWD. Warna merah ini menunjukkan bahwa area tersebut meskipun keruh, tetapi dasar perairannya mengalami pendalaman secara relatif. Hal ini disebabkan arus yang cukup kuat pada area tersebut sehingga proses yang terjadi adalah pengikisan dasar perairan, dan bukan proses pengendapan atau sedimentasi.

Hasil lain dalam penelitian ini menunjukkan bahwa pada bagian tengah waduk mempunyai tren yang dinamis. Arus air yang kuat memungkinkan untuk menggerus dasar perairan lebih dalam [19]. Kecenderungan arus ini terjadi pada rentang tahun 2013-2014, tahun 2015-2016, dan tahun 2018-2019. Hal ini berdasarkan pada tren kenaikan nilai NDTI dan penurunan nilai RWD. Pada rentang tahun tersebut, pola yang terjadi adalah banyak area perairan yang berubah menjadi lebih keruh dan dasar perairannya menjadi lebih dalam. Sedimentasi di bagian tengah waduk terjadi pada rentang tahun 2016-2017. Identifikasi proses sedimentasi ini didasarkan pada tren kenaikan nilai NDTI dan RWD, sehingga kondisi perairan pada rentang tahun tersebut cenderung keruh dan dasar perairannya lebih dangkal. 


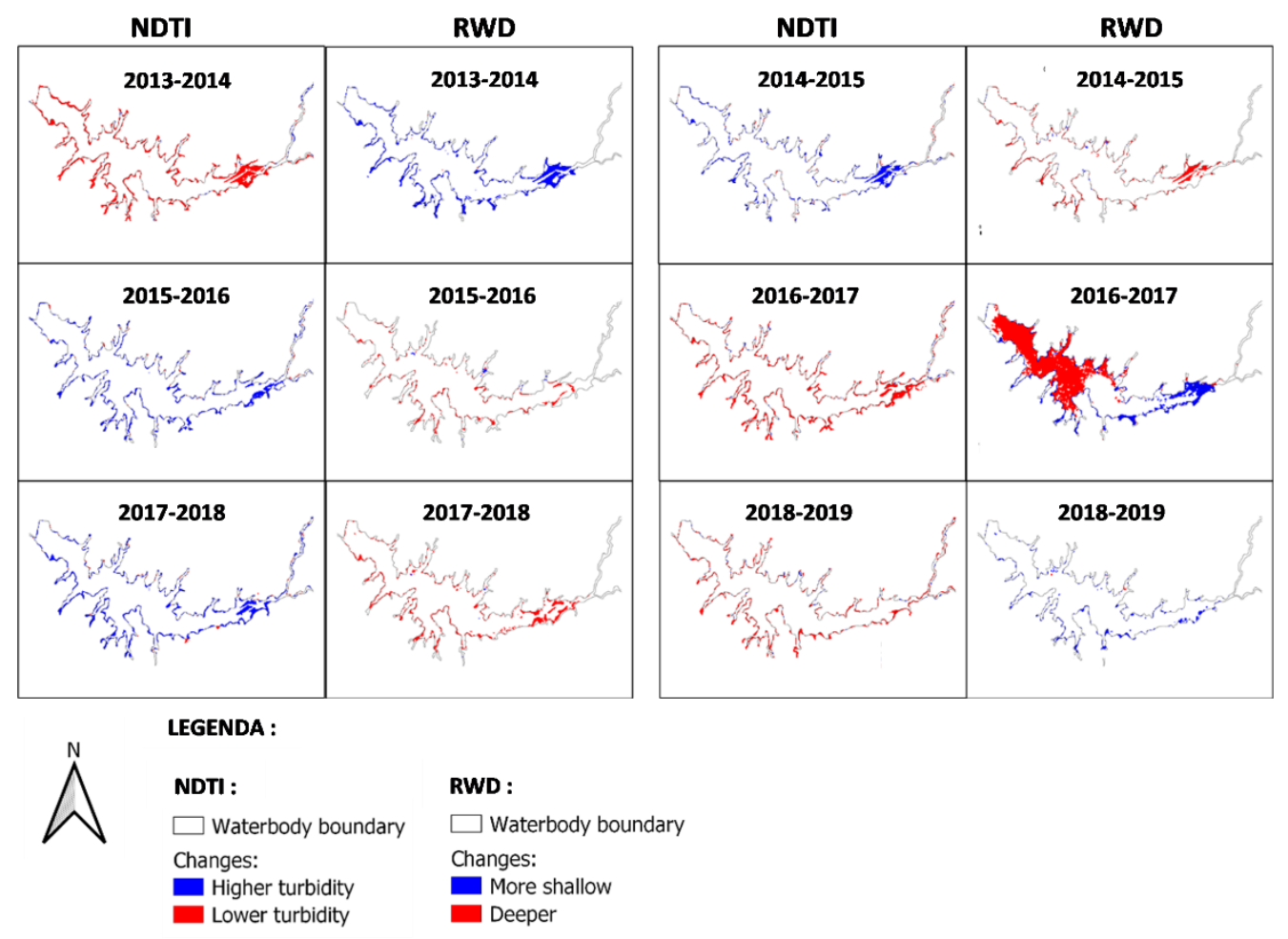

Gambar 6 Peta perubahan tingkat kedalaman relatif perairan Waduk Sutami tahun 2013-2019

Analisis statistik menunjukkan bahwa kekeruhan dan kedalaman perairan relatif tidak mempunyai korelasi yang kuat (Tabel 1).

Tabel 1. Koefisien korelasi NDTI dan RWD

\begin{tabular}{ll}
\hline Tahun & Koefisien korelasi \\
\hline 2013 & 0,2629 \\
2014 & 0,0138 \\
2015 & 0,0483 \\
2016 & 0,1067 \\
2017 & 0,2573 \\
2018 & 0,0061 \\
2019 & 0,0561 \\
\hline
\end{tabular}

Hubungan antara kekeruhan dan kedalaman perairan tidak mempunyai pola yang jelas (Gambar 7).Perubahan tingkat kekeruhan pada suatu perairan juga tidak dapat memengaruhi secara langsung terhadap perubahan kedalaman relatif dasar perairan. Faktor pengontrol yang memungkinkan untuk memengaruhi perubahan kedalaman dasar perairan adalah kuat arus air [19], [20], material dasar perairan [34], bentuk saluran air/sungai dan bentuk topografi dasar perairan [17]. 

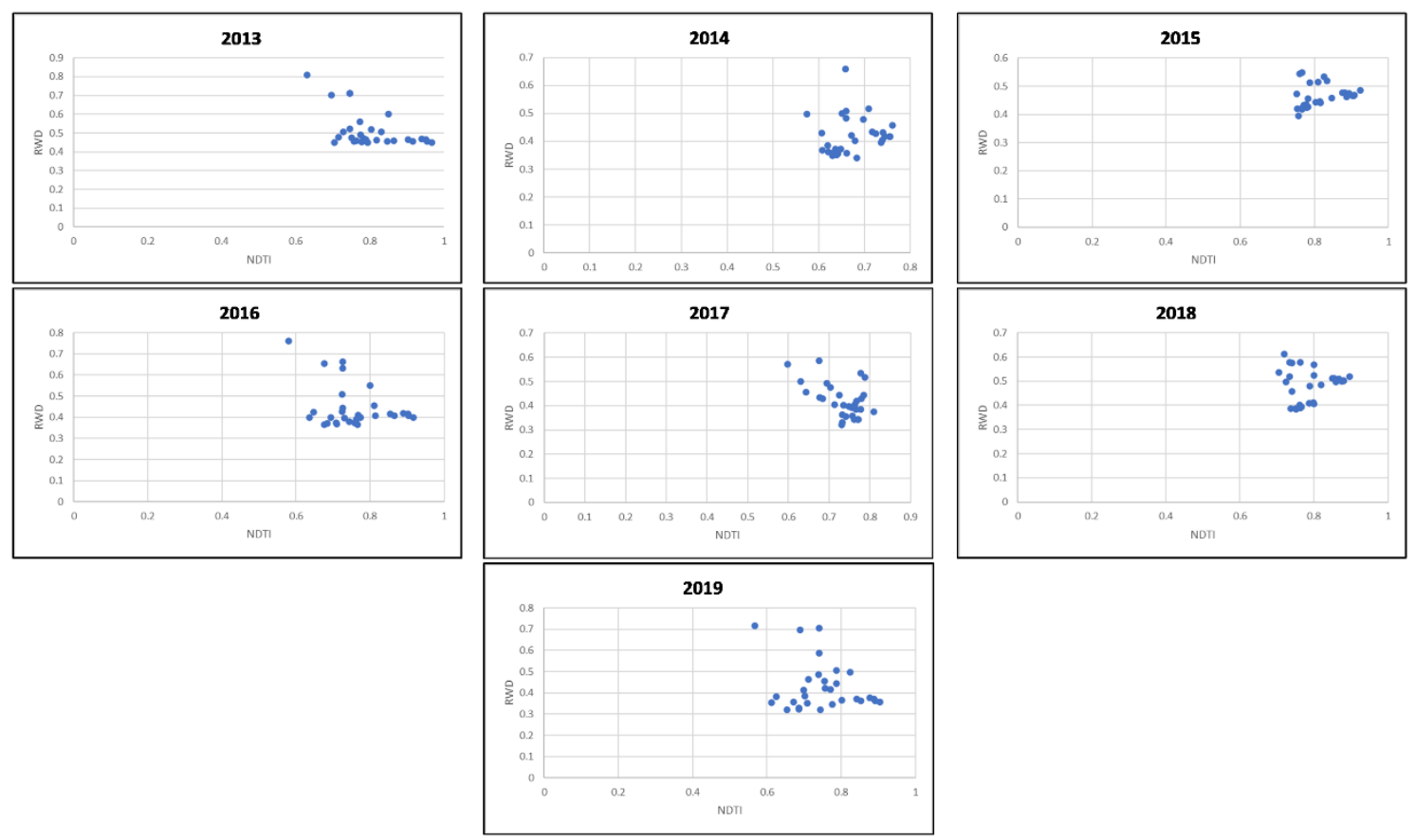

Gambar 7. Sebaran dan korelasi nilai NDTI dan RWD tahun 2013-2019

Tingkat kekeruhan air dapat dijadikan sebagai indikasi utama bahwa suatu perairan mengandung material terlarut yang dapat memberikan kontribusi bagi proses sedimentasi perairan [14].

Hubungan antara tingkat kekeruhan dengan kedalaman relatif perairan difokuskan di bagian tengah perairan. Jika analisis hubungan ini juga dilakukan pada bagian tepi perairan waduk, maka hasil keluaran dapat menjadi bias, terutama hasil yang terkait dengan analisis NDTI untuk identifikasi tingkat kekeruhan. Hasil penelitian lain menunjukkan bahwa nilai bias ini dapat terjadi apabila terdapat bentukan budidaya di atas perairan tersebut atau perairan yang diamati merupakan perairan yang tidak homogen [35]. Penelitian tersebut menegaskan bahwa citra Landsat memberikan hasil analisis sedimentasi yang baik pada area yang tidak mempunyai kesan perbedaan rona yang jelas (gelap atau terang) pada perairan, misalnya pada bagian tengah perairan.
Waduk Sutami sering dimanfaatkan oleh penduduk sebagai lahan budidaya tambak, sehingga perairan di bagian tepi menjadi terkesan tidak homogen. Penelitian ini memperkuat pernyataan penelitian sebelumnya bahwa jika diinterpretasi secara visual pada bagian tepi waduk, maka lahan budidaya tambak tersebut tampak seperti perairan keruh. Semakin perairan tampak keruh secara visual, maka nilai NDTI juga akan semakin mendekati 1. Perairan yang telah dimanfaatkan menjadi lahan budidaya dapat menurunkan akurasi identifikasi tingkat kekeruhan perairan menggunakan NDTI. Nilai NDTI yang dihasilkan bukan hanya merupakan hasil respons spektral obyek perairan saja, namun nilai respon spektral tersebut telah dipengaruhi oleh respon spektral dari obyek yang lain, yaitu bangunan budidaya yang ada di perairan tersebut. NDTI akan lebih akurat untuk digunakan pada identifikasi tingkat kekeruhan perairan apabila tidak ada bentukan budidaya apa pun di perairan tersebut. 


\section{KESIMPULAN}

Kondisi perairan waduk Sutami pada tahun 2013 hingga tahun 2019 menunjukkan bahwa kenampakan air keruh cenderung teridentifikasi di bagian timur waduk yang juga merupakan inlet waduk Sutami. Area-area yang mengalami peningkatan tingkat kekeruhan, ternyata diikuti dengan peningkatan kedalaman relatif perairan, baik pada bagian tepi maupun tengah waduk.

Tingkat kekeruhan dan kedalaman relatif perairan tidak berhubungan kuat secara statistik. Hubungan kedua variabel tersebut dipengaruhi oleh variabel kontrol yaitu sedimentasi dan topografi perairan tersebut Hasil ini menegaskan bahwa semakin keruh suatu perairan, maka belum tentu kedalaman relatif pada perairan tersebut menjadi semakin dangkal.

\section{DAFTAR PUSTAKA}

[1] M. M. R. Tabari, M. N. Azadani, and R. Kamgar, Development of operation multi-objective model of dam reservoir under conditions of temperature variation and loading using NSGA-II and DANN models: a case study of Karaj/Amir Kabir dam, vol. 24, no. 16. Springer Berlin Heidelberg, 2020.

[2] D. Ralston, B. Yellen, and J. Woodruff, "Watershed sediment supply and potential impacts of dam removals for an estuary," Earth Sp. Sci. Open Arch., no. Lane 1955, 2020.

[3] A. Mohseni-Bandpei et al., "Water quality assessment of the most important dam (Latyan dam) in Tehran, Iran," Environ. Sci. Pollut. Res., vol. 25, no. 29, pp. 29227-29239, 2018.

[4] J. C. Alais, P. Carpentier, and M. De Lara, "Multi-usage hydropower single dam management: chance-constrained optimization and stochastic viability," Energy Syst., vol. 8, no. 1, pp. 7-30, 2017.

[5] M. F. G. Brito, V. S. Daga, and J. R. S. Vitule, "Fisheries and biotic homogenization of freshwater fish in the Brazilian semiarid region," Hydrobiologia, vol. 847, no. 18, pp. 3877-3895, 2020.

[6] Dinas Komunikasi dan Informatika Pemerintah Provinsi Jawa Timur, "Sebesar 90\% Air Bendungan Sutami Untuk Irigasi Pertanian," 2018. [Online]. Available: http://kominfo.jatimprov.go.id/read/um um/sebesar-90-air-bendungan-sutamiuntuk-irigasi-pertanian.

[7] Perusahaan Umum (Perum) Jasa Tirta 1, "Laporan Tahunan Perusahaan Umum (Perum) Jasa Tirta I Tahun 2018," Malang, 2019.

[8] V. Mano, J. Nemery, P. Belleudy, and A. Poirel, "Assessment of suspended sediment transport in four alpine watersheds (France): influence of the climatic regime," Hydrol. Process., vol. 23, no. 5, pp. 777-792, 2009.

[9] S. Bid and G. Siddique, "Identification of seasonal variation of water turbidity using NDTI method in Panchet Hill Dam, India," Model. Earth Syst. Environ., vol. 5, no. 4, pp. 1179-1200, 2019.

[10] S. Afshar, A. Shamsai, and B. Saghafian, "Dam sediment tracking using spectrometry and Landsat 8 satellite image, Taleghan Basin, Iran," Environ. Monit. Assess., vol. 188, no. 2, pp. 1-10, 2016.

[11] I. E. Issa, N. Al-Ansari, G. Sherwany, and S. Knutsson, "Evaluation and modification of some empirical and semi-empirical approaches for prediction of area-storage capacity curves in reservoirs of dams," Int. J. Sediment Res., vol. 32, no. 1, pp. 127135, 2017.

[12] S. R. Chalov, V. O. Bazilova, and M. K. Tarasov, "Modelling suspended sediment distribution in the selenga river delta using LandSat data," Proc. Int. Assoc. Hydrol. Sci., vol. 375, no. August 1993, pp. 19-22, 2017.

[13] L. H. Trinh et al., "Estimation of suspended sediment concentration using VNREDSat - 1A multispectral data, a case study in Red River, Hanoi, 
Vietnam," Geogr. Environ. Sustain., vol. 11, no. 3, pp. 49-60, 2018.

[14] X. Xu, H. Fan, X. Chen, and C. Mi, "Estimating low eroded sediment concentrations by turbidity and spectral characteristics based on a laboratory experiment," Environ. Monit. Assess., vol. 192, no. 2, 2020.

[15] M. Bergen et al., "Relationship between depth, sediment, latitude, and the structure of benthic infaunal assemblages on the mainland shelf of southern California," Mar. Biol., vol. 138, no. 3, pp. 637-647, 2001.

[16] A. Krajewski and A. E. SikorskaSenoner, "Suspended sediment routing through a small on-stream reservoir based on particle properties," J. Soils Sediments, 2021.

[17] T. Sabzevari and A. Talebi, "Effect of hillslope topography on soil erosion and sediment yield using USLE model," Acta Geophys., vol. 67, no. 6, pp. 15871597, 2019.

[18] A. Sadeghian, J. Hudson, H. Wheater, and K. E. Lindenschmidt, "Sediment plume model - a comparison between use of measured turbidity data and satellite images for model calibration," Environ. Sci. Pollut. Res., vol. 24, no. 24, pp. 19583-19598, 2017.

[19] A. Movahedi, M. R. Kavianpour, and O. Aminoroayaie Yamini, "Evaluation and modeling scouring and sedimentation around downstream of large dams," Environ. Earth Sci., vol. 77, no. 8, pp. 1-17, 2018.

[20] E. Sebok, P. Engesgaard, and C. Duque, "Long-term monitoring of streambed sedimentation and scour in a dynamic stream based on streambed temperature time series," Environ. Monit. Assess., vol. 189, no. 9, 2017.

[21] R. Foteh, V. Garg, B. R. Nikam, M. Y. Khadatare, S. P. Aggarwal, and A. S. Kumar, "Reservoir Sedimentation Assessment Through Remote Sensing and Hydrological Modelling," J. Indian Soc. Remote Sens., vol. 46, no. 11, pp. 1893-1905, 2018.

[22] A. H. Zaji, H. Bonakdari, and B.
Gharabaghi, "Applying upstream satellite signals and a 2-d error minimization algorithm to advance early warning and management of flood water levels and river discharge," IEEE Trans. Geosci. Remote Sens., vol. 57, no. 2, pp. 902-910, 2019.

[23] A. H. Zaji, H. Bonakdari, and B. Gharabaghi, "Reservoir water level forecasting using group method of data handling," Acta Geophys., vol. 66, no. 4, pp. 717-730, 2018.

[24] K. A. Hakeem, P. V. Raju, E. S. Sankar, and S. Jonna, "Role of IRS-1C in Developing Remote Sensing Applications for Water Management in India," J. Indian Soc. Remote Sens., vol. 8, 2021.

[25] S. Yu and V. S. Mantravadi, "Study on Distribution Characteristics of Suspended Sediment in Yellow River Estuary Based on Remote Sensing," $J$. Indian Soc. Remote Sens., vol. 47, no. 9, pp. 1507-1513, 2019.

[26] C. Zhan et al., "Remote sensing retrieval of surface suspended sediment concentration in the Yellow River Estuary," Chinese Geogr. Sci., vol. 27, no. 6, pp. 934-947, 2017.

[27] V. Garg et al., "Spectral similarity approach for mapping turbidity of an inland waterbody," J. Hydrol., vol. 550, pp. 527-537, 2017.

[28] W. H. Chien, T. S. Wang, H. C. Yeh, and T. K. Hsieh, "Study of NDVI Application on Turbidity in Reservoirs," J. Indian Soc. Remote Sens., vol. 44, no. 5, pp. 829-836, 2016.

[29] J. Gardelle, P. Hiernaux, L. Kergoat, and M. Grippa, "Less rain, more water in ponds: A remote sensing study of the dynamics of surface waters from 1950 to present in pastoral Sahel (Gourma region, Mali)," Hydrol. Earth Syst. Sci., vol. 14, no. 2, pp. 309-324, 2010.

[30] J. P. Lacaux, Y. M. Tourre, C. Vignolles, J. A. Ndione, and M. Lafaye, "Classification of ponds from highspatial resolution remote sensing: Application to Rift Valley Fever epidemics in Senegal," Remote Sens. 
Environ., vol. 106, no. 1, pp. 66-74, 2007.

[31] M. K. Tarasov and O. V. Tutubalina, "Estimating the Water Turbidity in the Selenga River and Adjacent Waters of Lake Baikal Using Remote Sensing Data," Izv. - Atmos. Ocean Phys., vol. 54, no. 9, pp. 1353-1362, 2018.

[32] W. R. Normark, D. J. W. Piper, H. Posamentier, C. Pirmez, and S. Migeon, Variability in form and growth of sediment waves on turbidite channel levees, vol. 192, no. 1-3. 2002.

[33] R. B. Wynn and D. A. V. Stow, "Classification and characterisation of deep-water sediment waves," Mar. Geol., vol. 192, no. 1-3, pp. 7-22, 2002.

[34] M. M. Nasr-Azadani and E. Meiburg, "Influence of seafloor topography on the depositional behavior of bi-disperse turbidity currents: A three-dimensional, depth-resolved numerical investigation," Environ. Fluid Mech., vol. 14, no. 2, pp. 319-342, 2014.

[35] Y. Darama, Z. Selek, B. Selek, M. A. Akgul, and M. Dagdeviren, "Determination of sediment deposition of Hasanlar Dam using bathymetric and remote sensing studies," Nat. Hazards, vol. 97, no. 1, pp. 211-227, 2019.

[36] J. F. Mas, "Mapping land use/cover in a tropical coastal area using satellite sensor data, GIS and artificial neural networks," Estuar. Coast. Shelf Sci., vol. 59, no. 2, pp. 219-230, 2004.

[37] H. Jiang et al., "Remote Sensing Reversion of Water Depths and Water Management for the Stopover Site of Siberian Cranes at Momoge, China," Wetlands, vol. 35, no. 2, pp. 369-379, 2015.

[38] D. R. Lyzenga, "Passive remote sensing techniques for mapping water depth and bottom features," Appl. Opt., vol. 17, no. 3, pp. 379-383, Feb. 1978.

[39] M. A. Fonstad and W. A. Marcus, "Remote sensing of stream depths with hydraulically assisted bathymetry (HAB) models," Geomorphology, vol. 72, no. 1-4, pp. 320-339, 2005.

[40] E. M. Louchard, R. P. Reid, F. C.
Stephens, C. O. Davis, R. A. Leathers, and D. T. Valerie, "Optical remote sensing of benthic habitats and bathymetry in coastal environments at Lee Stocking Island, Bahamas: A comparative spectral classification approach," Limnol. Oceanogr., vol. 48, no. 1part2, pp. 511-521, 2003.

[41] D. G. Hadjimitsis, M. G. Hadjimitsis, C. Clayton, and B. A. Clarke, "Determination of Turbidity in Kourris Dam in Cyprus Utilizing Landsat TM Remotely Sensed Data," Water Resour. Manag., vol. 20, no. 3, pp. 449-465, 2006.

[42] R. P. Stumpf, K. Holderied, and M. Sinclair, "Determination of water depth with high-resolution satellite imagery over variable bottom types," Limnol. Oceanogr., vol. 48, no. 1part2, pp. 547556, 2003.

[43] K. C. Tan, H. S. Lim, M. Z. MatJafri, and K. Abdullah, "A comparison of radiometric correction techniques in the evaluation of the relationship between LST and NDVI in Landsat imagery," Environ. Monit. Assess., vol. 184, no. 6, pp. 3813-3829, 2012.

[44] X. Jiang and Y. Wei, "Erosion characteristics of outburst floods on channel beds under the conditions of different natural dam downstream slope angles," Landslides, vol. 17, no. 8, pp. 1823-1834, 2020.

[45] M. Abdellah, H. Mohamed, and D. Farouk, "The implication of climate change and precipitation variability on sedimentation deposits in Algerian dams," Arab. J. Geosci., vol. 11, no. 23, 2018.

[46] I. Kocaman, F. Konuccu, and A. Istanbulluoglu, "Research on the sedimentation and erosion problem of the Ergene River Basin in Western Turkey and precautions to control it," Eurasian Soil Sci., vol. 40, no. 10, pp. 1110-1116, 2007.

[47] G. M. Kondolf et al., "Sustainable sediment management in reservoirs and regulated rivers: Experiences from five continents," Earth's Futur., vol. 2, no. 
5, pp. 256-280, 2014.

[48] P. Espa, E. Castelli, G. Crosa, and G. Gentili, "Environmental Effects of Storage Preservation Practices: Controlled Flushing of Fine Sediment from a Small Hydropower Reservoir," Environ. Manage., vol. 52, no. 1, pp. 261-276, 2013.

[49] A. Doretto, T. Bo, F. Bona, M. Apostolo, D. Bonetto, and S. Fenoglio,
"Effectiveness of artificial floods for benthic community recovery after sediment flushing from a dam," Environ. Monit. Assess., vol. 191, no. 2, 2019.

[50] S. Dutta, "Soil erosion, sediment yield and sedimentation of reservoir: a review," Model. Earth Syst. Environ., vol. 2, no. 3, pp. 1-18, 2016. 